\title{
Correction to: School Climate Moderates the Association Between Sexual Harassment and Student Well-Being
}

\author{
Brittany Z. Crowley ${ }^{1}\left[\right.$ Dewey Cornell ${ }^{1} \cdot$ Timothy Konold $^{1}$
}

Published online: 26 July 2021

๑) Springer Science+Business Media, LLC, part of Springer Nature 2021

\section{Correction to: School Mental Health https://doi.org/10.1007/s12310-021-09449-3}

The original version of this article unfortunately contained a mistake. On page 11, the paragraphs "Data Availability" and "Code Availability" should be removed. They say that both the code and data are available upon request from the corresponding author, but upon reviewing the terms of the study IRB it became clear that the author actually cannot share the code or data. The original article has been corrected.

Publisher's Note Springer Nature remains neutral with regard to jurisdictional claims in published maps and institutional affiliations.

The original article can be found online at https://doi.org/10.1007/ s12310-021-09449-3.

Brittany Z. Crowley

bzc4kc@virginia.edu

1 School of Education and Human Development, University of Virginia, Charlottesville, USA 